\title{
“Um defunto não escreve nada por acaso": A recepção do mash up Memórias Desmortas de Brás Cubas na plataforma Skoob
}

\author{
Rebeca Fabiana Ferreira da Silva Santos $(U N E B)^{1}$ \\ https://orcid.org/0000-0002-3910-3053
}

Oton Magno Santana dos Santos (UNEB) ${ }^{2}$

https://orcid.org/0000-0002-6872-4799

\section{Resumo:}

Este estudo tem por objetivo averiguar de que forma os leitores da rede social colaborativa $S k o o b$, em ascensão no contexto de leitura brasileiro, concebem a proposta de apropriação textual efetivada pelo mash up literário Memórias Desmortas de Brás Cubas (2010), de Pedro Vieira, o qual deflagra o processo de releitura da obra clássica Memórias Póstumas de Brás Cubas (1881), de Machado de Assis. A pesquisa fundamenta-se na perspectiva da realçada figura do leitor na contemporaneidade, tendo como alicerce os pressupostos da Estética da Recepção, de Hans Robert Jauss (1982) e Karlheinz Stierle (1979). Esse aporte teórico subsidia a participação e criticidade da comunidade leitora em relação às obras que consome, perpassando por questões de valor estético, reconhecimento da figura do autor contemporâneo (apropriador) e aceitação da técnica de escrita apropriativa oriunda de um enredo canônico. Além dos teóricos supracitados, estudiosos como Roland Barthes (2004), Nicolas Bourriaud (2009), Antoine Compagnon (2003), Roger Chartier (2010), entre outros fundamentam este estudo. Palavras-chave: Machado de Assis; Leitor; Mash up; Recepção; Apropriação.

\section{Abstract:}

\section{"A deceased does not write anything by chance": The reception of the mash up Memórias Desmortas de Brás Cubas on the Skoob platform}

This study aims to investigate how readers of the collaborative social network Skoob, on the rise in the context of Brazilian reading, conceive the tex-

1 Mestranda no Programa de Pós-Graduação em Estudo de Linguagens da Universidade do Estado da Bahia, campus I. Email: rebeca.ff.ss@gmail.com.

2 Professor Adjunto. Programa de Pós-Graduação em Estudo de Linguagens - PPGEL. Universidade do Estado da Bahia - UNEB. E-mail: otonmagno@gmail.com. 
tual appropriation effected by the literary mash up Memórias Desmortas de Brás Cubas (2010), by Pedro Vieira , or triggers the process of re-reading the classic work Memórias Póstumas de Brás Cubas (1881), by Machado de Assis. The research is based on the perspective of the highlighted figure of the reader in contemporary times, having as basis the assumptions of Aesthetics of Reception, by Hans Robert Jauss (1982) and Karlheinz Stierle (1979). This theoretical subsidy subsidizes the participation and criticality of the reading community in relation to the works it consume, going through issues of aesthetic value, recognition of the figure of the contemporary author (owner) and acceptance of the appropriate writing technique derived from a canonical plot. In addition to the aforementioned theorists, scholars such as Roland Barthes (2004), Nicolas Bourriaud (2009), Antoine Compagnon (2003), Roger Chartier (2010), among other foundations of this study.

Keywords: Machado de Assis; Reader; Mash up; Reception; Appropriation.

\section{Considerações iniciais}

No âmbito da música, das artes visuais e audiovisuais contemporâneas, as montagens oriundas de objetos de várias origens constituem obras novas, sem maiores problemas estéticos ou críticas quanto à sua "autenticidade". Já no segmento literário, ainda existem muitos obstáculos que preenchem a obra mixada (consolidada através de apropriações textuais) de julgamentos pejorativos, frutos de uma crítica literária e de uma recepção fortemente dispostas a impor critérios e rejeitar como valoroso aquilo que não é "criativo".

O mash up literário é uma técnica de apropriação textual que propicia uma "mixagem literária" e se coaduna com a dissolução da imagem do leitor como sujeito passivo; é caracterizado pela junção de uma ou mais obras/produções em uma mesma produção textual. 0 termo mash up é originário da área da informática; traduzindo para o português, a expressão significa misturar, mesclar, surgindo, na área da computação, como uma técnica que propicia o recorte de elementos de fontes diversas para que se agrupem com outra finalidade.
A técnica do mash up literário consiste na aglutinação, mais precisamente, de obras literárias clássicas -, para que, dessa forma, se constitua uma nova obra. Além da mescla entre as obras, também são inseridos elementos da cultura de massa ao enredo da obra nova, a exemplo de vampiros, bruxas, alienígenas, mutantes - elementos fantásticos ao público leitor na contemporaneidade. Essa técnica é realizada por um processo criterioso de seleção de passagens e aspectos relevantes da obra primeira, assim se configurando como uma prática de intertextualidade. A obra mixada, ainda que desenvolva perspectivas novas acerca da leitura do enredo, deve preservar elementos - ainda que de forma implícita - que permitam identificar na obra contemporânea a presença do enredo original.

A paródia, outro exemplo de apropriação ou "empréstimo" textual ou temático, com referências diretas da obra-fonte, configura-se enquanto uma crítica destrutiva e irônica a uma produção textual; nela, quase sempre é empregada uma denúncia dotada de escárnio. Apesar de imitar criativamen- 
te um texto preexistente (CEIA, 2010), essa técnica ainda não é bem vista no meio literário. Embora, em alguns casos, seja motivo de entretenimento para leitores, para autores que têm suas obras parodiadas (alguns ainda em vida) pode ser motivo de melindre, julgamento ou até de processos na esfera jurídica.

O mash up literário se isenta de qualquer enquadramento de plágio ou bricolagem devido ao fato de as releituras serem embasadas em obras já disponíveis em domínio público, após 70 anos de falecimento do seu autor - em território nacional (RODRIGUES, 2013, p.49). De forma endossada, a prática ainda funciona como uma espécie de "autoria derivada", marcada "[...] pela capacidade de retomar a trajetória de retextualização revitalizando o texto fonte na memória coletiva" (BUZATO, 2013, p. 1209).

As técnicas de apropriação textual atendem a uma nova perspectiva no segmento da literatura contemporânea. Para além de uma nova forma de composição textual,

[...] a apropriação é tão mais interessante quanto maior for a habilidade do autor [...]. Não é apenas o fato de um trabalho ser feito por meio de apropriação que o torna interessante, mas a maneira como se maneja a linguagem apropriada, como se trata o texto, de que forma o leitor/pensador é engajado nas questões apresentadas e quais questões são essas disparadas pelo trabalho realizado (VILLA-FORTE, 2019, pp. 207-208).

No campo literário, falar em apropriação textual é ainda ruidoso, pois as técnicas de (re)escrita em questão parecem sugerir, para o público consumidor e para a crítica literária, que quem as executa não possui habilidade suficiente para produzir tão bons escritos como os que deram origem a uma nova produção. Há uma hierarquia entre autores canônicos e autores contempo- râneos que os releem, sendo aqueles colocados como superiores a esses últimos, por terem o mérito de criar obras em "primeira mão" ou originais, como costumam ser vistas as obras clássicas. Essa estigmatização de tipos de leitura tem raízes no movimento iluminista, o qual preconizava a leitura de obras da elite cultural, ou da chamada alta cultura, como única forma de deter conhecimento. Os demais tipos de leituras, escritos à margem, eram vistos como prejudiciais para a formação do intelecto do indivíduo leitor (MELLO, 2017, p. 85). Esse tipo de pensamento ainda encontra espaço em meio social e cultural, em certa medida, associando a ideia de uma boa leitura àquela que provém de uma elite letrada e canônica.

Todavia, conforme ressalta Sayonara Oliveira (2015, págs. 32-33), "No contexto atual, o funcionamento das instâncias de produção artística e cultural se altera, reorientando as condições nas quais os produtores exercem suas atividades junto a um mercado cada vez mais expandido". Em se tratando do panorama literário pós-moderno, abrangendo a disposição das obras que se apropriam de textos clássicos, convém ressaltar que um texto enquadrado no segmento da literatura é tido como um espaço vazio, um gerador de atividades, segundo Nicolas Bourriaud (2009), as quais implicam, principalmente, na semantização empreendida pelo leitor durante a leitura. 0 texto, então, não é independente; para além do ato da escrita e da relevância da figura autoral, estão a forma como ele será recebido pelo público e de que forma ele será colocado no acervo intelectual pessoal do leitor.

No que diz respeito à forma com a qual o leitor visualiza essas práticas apropriativas, é preciso ressaltar que a recepção de textos 
literários funciona como uma cadeia de produção de sentidos (OLIVEIRA, 2015, p. 31). Todo leitor, a partir de leituras e vivências particulares, acumula um repertório de escritas que permeiam as suas expectativas perante leituras a serem realizadas e outras que não terão sua aceitação. Assim, à medida em que as leituras empreendidas no decorrer do tempo sofrem mudanças, entende-se que os juízos de valor, que compõem uma cadeia de recepções das obras, também podem mudar (ibidem, p. 43).

\section{O leitor na contemporaneidade}

Durante muito tempo, conforme afirma Roberto Reis (1992, págs. 8-9), a constituição do sistema literário foi embasada pela preservação de uma norma estética, a qual atendia aos interesses de escritores canônicos, em função de uma literatura elitizada, reflexo do atendimento dos interesses ainda em voga no meio social. Os formalistas russos e os New Critics consideravam o texto literário como um objeto a ser analisado de forma orgânica, condicionado a uma materialidade; para esses estudiosos, ele existia de forma autônoma. Uma vez que o texto funcionava como um "laboratório fechado", não haveria espaço para a apreensão de sentidos por parte do leitor, sendo esse "banido" do contexto em questão (COMPAGNON, 2003, p. 140-141). Somente após esse período, pôde se considerar uma sutil conquista de espaço para o leitor, dessa vez, vislumbrado como um ledor ideal que, debruçado perante o texto, ceifava qualquer interferência pessoal que não se adequasse às pré-estabelecidas "expectativas do texto".

Segundo Luiz Costa Lima (1979, p. 10), a figura do leitor, a qual reivindica cada vez mais espaço no segmento literário, é o nú- cleo da Estética da Recepção, corrente que ganhou força após a Aula inaugural de Hans Robert Jauss, na década de 1960. A experiência estética, segundo o teórico, surge como uma esquiva à perpetuação da proibição, bem como alavanca a repaginação dos cânones, possibilitando a circulação de novos meios de expressão na indústria cultural. No intuito de sair do âmbito das percepções acomodadas, a figura do ledor é fundamental para repensar de que forma se instauram mudanças (estéticas e autorais) no segmento da história da literatura (ZAPPONE, 2009, p. 154).

Alguns estudiosos, no decorrer do tempo, passaram a se aprofundar na importância do efeito causado pela obra no receptor. Assim, houve um foco maior na forma como o leitor se sentia perante uma obra, no ato da leitura. Considerou-se, dessa forma, que o texto literário só pode ser consolidado como tal se existir um receptor que dele depreenda sentido, tornando-o, assim, um leitor real. Assim ressalta Mirian Zappone (2009, p. 153), ao afirmar que uma vez que o texto não diz tudo, tampouco o escritor pode atribuir um sentido exclusivo para sua produção.

Os indivíduos que se beneficiam dos produtos culturais em circulação que, anteriormente, restringiam a sua participação no segmento cultural somente ao consumo, se sentem mais respaldados para exercerem criticidade acerca do que consomem. 0 dito "público não especializado" está reivindicando e compondo espaços intelectuais, outrora ocupados tão somente por camadas sociais privilegiadas ou historicamente/ epistemologicamente autorizadas, carregando "[...] consigo uma bagagem cultural de que não pode abrir mão e que interfere na recepção de uma criação literária particular" (ZILBERMAN, 2008, p. 92). 


\section{Memórias desmortas de brás cubas}

Memórias Desmortas de Brás Cubas (2010) é uma produção apropriativa que está atrelada à Tarja Editorial, escrita por Pedro Vieira; formado em Letras pela Universidade do Estado do Rio de Janeiro, iniciou o mestrado em Letras pela mesma instituição. Além disso, é autor do livro Nerdquest (2008), lançado pela Editora 7letras.

A obra se apresenta, conforme a capa, como "o clássico machadiano agora com zumbi, caos e carnificina". 0 enredo se desvela como uma continuação do clássico de Machado de Assis, com a apresentação da "saga zumbi" de Brás Cubas, em torno do advento da descoberta do emplasto anti-hipocondria. 0 prólogo explicita como se apresenta a produção e "para quem", parodiando a obra clássica machadiana: "A todos os jovens alunos que foram forçados a ler minhas primeiras Memórias Póstumas, dedico estas memórias como forma de retribuição". Na trama, também encontram-se elementos de outras obras machadianas, como Quincas Borba (1891), O Alienista (1882) e A Cartomante (1884). A personagem de Brás Cubas, oriunda do enredo canônico, é ressuscitada pelo criado Prudêncio, que viola seu túmulo em busca do emplasto enterrado consigo - elemento também presente na narrativa machadiana. Numa reação de conotação fantástica, Brás Cubas ataca o criado, e o devora parcialmente, tirando a sua vida e tornando-o seu aliado numa espécie de apocalipse zumbi: "Por motivos óbvios eu nunca havia assistido a A Madrugada dos Mortos ou nenhum dos clássicos do gênero. Não tinha ideia do que havia me tornado" (VIEIRA, 2010, págs. 17-18). Juntos, eles saem em busca de novas vítimas, tornando suas aventuras regadas de muitas referências contemporâneas e elementos condizentes com uma carnificina, como sangue, miolos e demais entranhas.

O livro se propõe não somente a repaginar o enredo clássico, como também sugere uma continuidade à obra Memórias Póstumas de Brás Cubas (1881), na qual, agora de forma escancarada, o protagonista, para além de escrever, prepara-se para uma caçada por vítimas que o alimentem enquanto zumbi. Embora ambas as obras possam ser enquadradas como ficções (quase científicas), devido ao fato de relatarem o enredo acerca das vivências de uma personagem já morta, a qual, por vias naturais, não pode narrar nada, a obra segunda encontra mais obstáculos na aceitação devido ao nome do autor em ascensão, aos elementos utilizados para a sátira e a mescla de contextos distintos, propiciando uma possibilidade maior de estranhamento perante a crítica e os leitores.

É recorrente, durante o enredo, que o escritor contemporâneo empregue uma sátira que toma como empréstimo da escrita de Machado de Assis, porém, na obra apropriadora, o faz de forma mais escancarada, utilizando-se de elementos condizentes com a atualidade e com crenças hoje cotidianas, a exemplo da temática do apocalipse zumbi, a menção de séries televisivas, personagens de outras obras, expressões usadas em redes sociais, entre outros elementos, como ilustra o trecho abaixo:

Mal vejo a hora de ter os direitos dessas memórias vendidos para o cinema. Por isso já sugiro a trilha sonora da cena anterior, a carnificina pelo centro do Rio Antigo: Queen, I want to break free. 0 que vocês acham, Leitores? Sim, vou engordar minha conta bancária morta-viva a custa de vocês, meus queridinhos, que comprarão este livro, em seguida a edição especial ilustrada, depois o álbum de figurinhas, as actionfigures, jogos 
de tabuleiro, card games, a série de histórias em quadrinhos As aventuras do sensacional Zumbrás, que é o meu alter-ego de super-herói [...] (VIEIRA, 2010, p. 53).

Ao contrário do que era esperado, conforme a época do lançamento do livro (a mesma em que os mash ups da coleção Clássicos Fantásticos ${ }^{3}$ foram lançados pela Editora Leya), o autor da obra apropriativa, Pedro Vieira, entra em desacordo quanto ao enquadramento da sua produção. Alguns leitores e escritores de blogs visualizam e classificam a obra como um mash up literário, enquanto o escritor a considera uma paródia. No geral, os textos-paródia são os que realizam o papel de imitar ou reproduzir um escrito de forma pejorativa e sarcástica, sem nenhum outro objetivo principal para além da crítica.

O autor da obra contemporânea, em entrevista concedida pela plataforma Gmail, relata que a intenção, ao escrever a obra, era contextualizar com os tempos atuais, o que é perceptível em algumas falas da personagem Brás Cubas, que usa expressões da atualidade, gírias, expressões em inglês, e, ainda, faz críticas diretas aos intelectuais/pesquisadores acadêmicos que tanto se ocupam em estudar os clássicos da literatura, dando ênfase à temática adotada em sua obra, como no trecho a seguir: "Veja como a literatura (ou no caso, a filosofia) se torna tão agradável e excitante, bastando o acréscimo de uma pitada de carnificina sanguinolenta" (VIEIRA, 2010, p. 48). Em outra passagem, a personagem deixa explícita a vontade dele a

3 A coleção Clássicos Fantásticos da Editora LeYa é composta pelos seguintes títulos: Dom Casmurro e os Discos Voadores (2010), de Machado de Assis e Lucio Manfredi; A Escrava Isaura e o Vampiro (2010), de Bernardo Guimarães e Jovane Nunes; Senhora, a Bruxa (2010), de José de Alencar e Angélica Lopes e 0 Alienista Caçador de Mutantes (2010), de Machado de Assis e Natália Klein. quem se propõe a história (o escrito), qual a preferência do público que deseja alcançar, de forma ácida e sarcástica:

[...] este texto não é pra você, intelectualoide de plantão, que vai escrever um trabalho pífio para o mestrado e depois uma tese patética de doutorado, e por fim há de compor um deveras xexelento pós-doutorado, vivendo o resto de sua existência infeliz à custa de distorcer minhas Memórias (VIEIRA, 2010, p. 20).

Da mesma forma, Pedro Vieira ainda confessa que o texto se trata de uma continuação do que teria ocorrido na obra de Machado de Assis, - tempos depois do falecimento e do silenciamento do defunto autor da obra clássica - e não um mash up, “[...] no sentido em que o texto original tenha sido 'remixado', eu usei esse artifício pra não passar vergonha tentando emular o texto de Machado".

Independentemente de como a obra seja classificada diante da crítica literária ou do público leitor, não há prejuízo na proposta inicial de ressignificar a temática da obra clássica que é apropriada. Dessa forma, $M e$ mórias Póstumas de Brás Cubas se mantém, de certa forma, ainda em circulação no panorama da leitura da contemporaneidade. 0 processo de releitura, ainda passível de uma recepção mais proveitosa no contexto literário justifica sua relevância a nível de produção textual, uma vez que "[...] parte-se desse mundo de mercado, cotidiano e familiar para o leitor, a fim de reciclá-lo em algo incomum, surpreendente, criativo" (VILLAFORTE, 2019, p. 77).

O lançamento de obras como essas elenca uma série de problemáticas dentro e fora do âmbito literário, dentre as quais se destacam o aval para o mash up literário, os textos -paródia e demais tipos de apropriação textual, a relação produtor-consumidor, a qual 
subsidia a recepção dos leitores deflagrada, sobretudo, em meio digital, onde circulam com mais fluidez, opiniões e pareceres, formais ou informais, sobre as mais diversas temáticas pertinentes ao segmento cultural contemporâneo.

\subsection{A plataforma de leitura skoob}

Em meio ao contexto de interação e participação do público leitor em relação às obras que consomem, é cada vez mais comum encontrar plataformas digitais (redes sociais colaborativas) de leitura e trocas de informações acerca de obras ou textos menores lidos. Esse tipo de ferramenta se consolidou com o objetivo de aproximar leitores, fazendo-os compartilhar seus gostos pessoais e pareceres sobre o que leem. Em destaque para essa pesquisa, está a plataforma Skoob, lançada em 2009 pelo desenvolvedor Lindemberg Moreira. A plataforma propicia a troca de informações, feedbacks, resenhas, comentários entre escritores e ledores. 0 site, hoje, conta com a participação de 5.900 .000 (cinco milhões e novecentos mil) usuários. 0 domínio da Internet ainda permite a visualização dos perfis dos usuários, juntamente com seu histórico de comentários, livros os quais leram, traçando uma espécie de "biblioteca individual" dos leitores. Nesse contexto participativo e de fluida circulação de opiniões, ressalta-se que

[...] nas origens da sociedade ocidental, aquele que tinha o discurso verdadeiro, tomado como verdade, era aquele indivíduo habilitado, que era autorizado a dizer, o nobre, o eleito, o sacerdote. Com o passar dos séculos, o discurso verdadeiro passou a ser aquele emitido por especialistas, estudiosos que testaram suas afirmações ou se debruçaram no estudo de um assunto específico. E assim foi durante séculos, até o surgimento do ciberespaço. Isso porque, com a Internet, todos têm acesso a tudo, o internauta tem voz e vez e os saberes que antes eram acessíveis por meio da opinião de um especialista hoje podem ser construídos coletivamente. O Skoob faz parte de tal contexto, pois [...] qualquer usuário pode escrever sua resenha e fazer sua análise [...] (Michel Foucault, 2009 apud BURLAMAQUE; BARTH, 2015, págs. 58-59).

Esses indivíduos podem interagir entre si e entre os administradores e editoras pertencentes ao site. Também conhecidos como skoobers, os usuários podem catalogar obras em seus perfis que desejam ler no futuro, classificá-las numa escala de 1 a 5 estrelas e elencá-las na seção de livros que já leram, estão relendo, que ainda desejam ler, que irão reler ou abandonaram a leitura. Também é possível manter uma lista de amigos, seguidores e usuários seguidos, enumerar editoras e autores preferidos (BURLAMAQUE; BARTH, 2015, págs. 56-57). Nas páginas correspondentes às obras, é possível identificar algumas informações a nível estatístico, como a quantidade de usuários que leram um determinado livro, a classificação geral (em estrelas), o apontamento de diferentes edições de uma obra e livros com enredo similar, bem como a descrição, o resumo, as resenhas dos leitores e até os valores pelos quais o livro está sendo vendido em diferentes locais.

A plataforma em questão é uma das poucas no Brasil que possui uma quantidade significativa de interação através de comentários que possibilitam visualizar como acontece a recepção da obra apropriativa em estudo, em relação aos usuários. A comunicação virtual, viabilizada por esse tipo de rede social, são instrumentos que propagam, de forma relevante, ideologias, culturas e identidades (CASTRO; SPINOLA, 2015, p. 171). 


\subsection{Miolos, sangue e carnificina: o que (mais) os skoobers têm a dizer?}

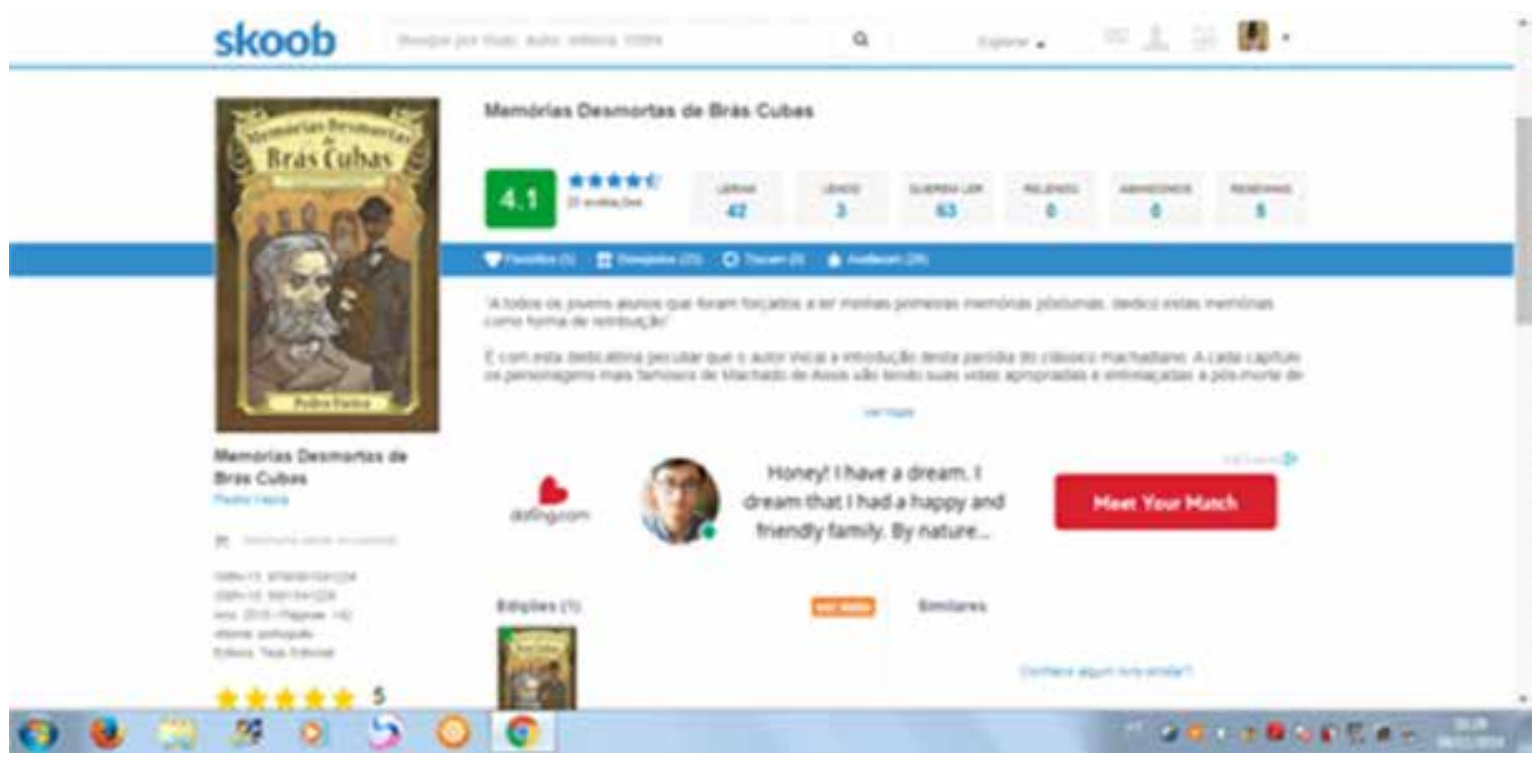

Fonte: Skoob

A imagem acima corresponde à página da obra Memórias Desmortas de Brás Cubas no site Skoob. Estabelecendo-se a data limite de coleta das informações disponíveis na página até $09 / 11 / 2019$, alguns dados foram observados e, posteriormente, registrados. Tem-se a avaliação geral de 4,1, contando com 63 (sessenta e três) leitores que desejam ler, 3 (três) que estão lendo e 42 (quarenta e dois) leitores efetivos da obra. Desse universo, 6 (seis) produziram resenhas(embora a página inicial tenha contabilizado cinco, é possível visualizar todas ao clicar na opção "resenhas"), as quais serão objeto de análise. Contando com 29 (vinte e nove) avaliações, 5 (cinco) usuários "favoritaram" a obra e 23 (vinte e três) colocaram na lista de desejos.

Do universo de resenhas, foi selecionada uma amostragem de 4 (quatro) resenhas, correspondentes a comentários que fomentam maiores discussões, completos (sem redirecionar a blogs pessoais para dar continuidade), os quais perpassam por reflexões acerca da (noção de)autoria e questões pertinentes à temática ofertada pela releitura do clássico. Os pronunciamentos dos leitores do Skoob, respaldados por um comportamento mais ativo em meio a um produto cultural consumido, denunciam "[...] um modo de leitura que rompe o isolamento e a distância do escritor e o situa no espaço de uma interpelação permanente [...]" (OLIVEIRA, 2015, p. 144). Os usuários podem adotar seu verdadeiro nome (e sobrenome) ou um apelido/"nickname"; em ambos os casos, de qualquer forma, as resenhas foram transcritas, de forma fiel, para preservar a identidade deles, guardadas as devidas proporções. A seguir, o primeiro comentário do usuário de nome "Tauan", que atribuiu uma estrela ao livro:

Há tempos eu estava à procura deste livro para finalizar o que chamei de "série de clássicos revistos", como Dom Casmurro e os Discos Voadores, Senhora, a Bruxa e 0 Alienista Caçador de Mutantes. Foi muito bom tê-lo encontrado no Livros em Pauta, pois pude comprá-lo por um preço muito baixo. 
Do contrário seria uma lástima. Decepcionante, é o primeiro adjetivo que associo ao livro. Na sequência, penso em enfadonho, mal escrito, clichê e outras palavrinhas menos educadas... Para começar, diferentemente das outras revisões (citadas acima), este livro não se propõe a recontar a história original, mas a dar uma continuidade. Não entendo isso como uma paródia... 0 estilo do autor é pobre e imaturo; suas frases são mal construídas e repetitivas; enfim, ele envergonharia Machado! Um exemplos do que ele considera boa escrita:

"Mencionei, nas Memórias anteriores, que antes de morrer trabalhei arduamente em meu emplasto [...] irei finalmente dar mais detalhes de como essa maravilha funciona [aqui ele se enrola, faz uma confusão e não diz nada, depois continua]. Ou seja, eu disse que iria finalmente dar detalhes, mas não dei. Menti. Isso que dá confiar tanto assim em um morto..."

Vieira também mistura personagens de outras obras machadianas (como A Cartomante e 0 Alienista). Talvez possam interpretar que isso cria a sugestão de que os personagens conviviam na imaginação do Imortal, mas, para mim, isso soa caótico e cheira a "forçação de barra" [...] (Resenhas - Memórias Desmortas de Brás Cubas, 2015).

O leitor elenca, na sua resenha, expressões que trazem à tona conceitos referentes à qualidade literária de uma obra em relação à outra. Ele estabelece uma comparação ao afirmar que a obra de Machado de Assis é "melhor", concatenando com o conceito de originalidade, que ainda denota prestígio no contexto literário. Também denota que estaria mais insatisfeito se o valor pago pelo livro fosse maior; não elenca como uma produção valorosa, o que explicita ao uso dos termos “decepcionante", "enfadonho", "mal escrito", entre outros. Ao estabelecer uma comparação com outras produções apropriativas, que se delimitam na proposta do mash up literário, o usuário dá a entender que a obra em questão é difusa por não se enquadrar, na percepção dele, nem nessa técnica, nem na paródia; portanto, não carrega prestígio. Para além disso, estabelece uma crítica destrutiva ao enredo, pelo fato de elencar personagens e temáticas de diversas obras (literárias ou não).

Roland Barthes (2004, p.4) afirma que o escritor nunca produz algo, de fato, original, tendo ele a possibilidade de misturar escritas. A figura do autor canônico, por conta disso, pode passar a ser encarada sob nova perspectiva. Os escritos de um autor, há algum tempo considerados intocáveis sob pena de repulsão a quem ousasse transpor essa fronteira, hoje podem (e, às vezes, precisam) ser modificados.

Segundo Karlheinz Stierle (1979), a intertextualidade presente em um texto pode ir de encontro ou frustrar a expectativa do leitor. Prova disso é que se estabelece ainda uma hierarquia entre autores canônicos e autores contemporâneos que os releem, sendo os primeiros colocados como superiores aos segundos, por terem o mérito de criarem obras em "primeira mão", "originais" - ou seja, inéditas. Porém, segundo Villa-Forte (2019, p. 50), a concepção sobre o que é "literatura" se ressignifica, à medida em que os conceitos de leitura e escrita também sofrem mudanças. A produção que hoje não é vista como valorosa, daqui a alguns tempos pode ser mais prestigiada, $\mathbf{o}$ que depende, também, do perfil construído acerca da figura do autor e sua "capacidade de escrita".

Essa atenção voltada para a obra responsável pela releitura, não raramente, é direcionada numa perspectiva negativa, que coloca a apropriação textual enquanto forma de profanação de uma obra "sagrada” (ALMEIDA, 2017, p.572). Isso se dá pelo 
fato de existir uma cobrança de fidelidade e uma "aura" - energia, invólucro de um objeto único - que não deveria ser perdida num contexto de constantes produções, em confecções feitas, supostamente, à revelia, quebrando uma tradição literária - ou a hegemonia dos autores clássicos (BENJAMIN, 1968, p.168-169).

Procede-se à análise da próxima resenha, do usuário com nickname "Coruja”, o qual atribuiu quatro estrelas para a obra:

Um ano atrás eu estava no aeroporto em Lisboa, esperando o vôo para Paris (metida, eu? Imagina...), fazendo de conta que não tinha ninguém me olhando estranho depois de ver de relance a capa do livro com que eu estava abraçada.

Eram as Memórias Desmortas de Brás Cubas e não tenho bem certeza, mas acho que o 'gajo' sentado ao meu lado achou que eu era algum tipo de sociopata ou coisa do tipo pela combinação de escolha de leitura e risadas. Ou então que a qualquer momento eu me levantaria babando e dizendo 'miolos...'

Memórias Desmortas de Brás Cubas continua de onde o clássico machadiano parou: após rememorar sua existência, Brás Cubas passa a contar como despertou no túmulo por obra e graça de seu magnífico emplasto; foi desenterrado por seu ex-escravo Prudência, que estava atrás da fórmula do mesmo e prontamente atacou o camarada e devorou seu cérebro.

Em morte, Cubas continua obcecado pelas mesmas coisas que dominavam sua vida: o emplasto 'panacéia universal' e Virgínia - e no caminho para chegar aos dois ele cruza com outros ícones do Bruxo do Cosme Velho (impagável seu encontro com o Alienista), produz uma horda de zumbis e um rastro de destruição bastante sangrento.

O livro é divertido e bem mais inteligente em seus trocadilhos, encontros e desencontros que Orgulho e Preconceito e Zumbis - que me parece ter sido o primeiro do gênero dos mash-ups. Isso porque não existe apenas um recontar da história original com o acréscimo de qualquer que seja a criatura sobrenatural de escolha, mas existe um enredo novo e Brás Cubas, conversando diretamente com o leitor, critica como suas memórias originais foram apropriadas por academicistas que tiram todo o prazer da leitura ao mesmo tempo em que forçam adolescentes sem maturidade a ler um texto denso e decorar fórmulas, traumatizando a criatura pelo resto da vida.

É, enfim, um volume bem divertido, que dá algo no que pensar, com um sem número de referências curiosas e marcantes. Só tenha cuidado para não escorregar no sangue e vísceras deixados pelo caminho... [...] (Resenhas - Memórias Desmortas de Brás Cubas, 2013).

Em seu comentário, o usuário mostra um entusiasmo e ansiedade para ler a obra, ao mesmo tempo em que se mostrava acanhada pela possibilidade de verem a sua reação diante daquela obra em especial. Certamente, não se preocuparia se demonstrasse o mesmo comportamento entusiasta ao se deparar com uma obra clássica; porém, deve ser sabido pela leitora que, desde a capa até o conteúdo da obra, pode ser alvo de julgamentos. A leitora ainda estabelece uma comparação entre a obra apropriadora em estudo e outra, que relê um clássico estadunidense (Orgulho e Preconceito e Zumbis), tentando equiparar os enredos e elencando a obra de Vieira como mais divertida e inteligente, o que denota que o texto alcançou as expectativas esperadas por ela, o que na Estética da Recepção pode ser vislumbrado como horizonte de expectativa.

Cunhado por Jauss, o termo é alicerçado pelo que se chama de distância estética; quanto mais próxima ela esteja das expectativas do público leitor, menor pode ser o valor estético da obra, o que chama de "arte 
ligeira", o que poderia ser um contraponto para os leitores, no sentido de ainda tentar hierarquizar produções literárias. Corrobora para isso o fato de que, frequentemente, "[...] as pessoas consideram como 'literatura' a escrita que lhes parece bonita" (EAGLETON, 2003, p. 14).

Porém, a concepção de prestígio de um autor, na atualidade, pode adquirir um caráter mais subjetivo, conforme a identificação do leitor com seus escritos. Assim corrobora LIMA (1979, p. 44):

Como, por exemplo, se estabelece o consenso sobre a excelência de um autor? Seria por que o horizonte de expectativas dos leitores se ajusta com o horizonte possibilitado pelo texto, numa espécie de contrato natural, ou por que instâncias de poder específico - isto é, do poder literário - se não mesmo as inclinações políticas da sociedade se manifestam e/ou se orientam em favor da concessão daquele prêmio?

Ao identificar as semelhanças entre o enredo novo e o de Machado de Assis, pela forma da escrita e preservação parcial dos contextos e das personagens, a leitora em questão denota familiaridade suficiente para identificar como essa relação se estabelece entre eles, aparentemente, de forma satisfatória/positiva. Com isso, é necessário ressaltar que "[...] por mais que seja transplantado para outros contextos, o âmago do texto original sempre estará presente, convidando tanto a crítica quanto o leitor a fazerem conjecturas sobre a matriz de onde surge o texto relido" (JESUS; PEREIRA, 2015, p. 156).

A seguinte resenha pertence ao usuário "Leonardo T., o qual atribuiu cinco estrelas à produção de Pedro Vieira:

Quando dei por mim já estava com esta obra em mãos! E as letras contidas no tomo anacrônico a devorar meu cérebro como famintos e, diga-se de passagem, impulsivos redivivos, não, melhor, desmortos! Sim! Estou falando de Memórias Desmortas de Brás Cubas, um dos lançamentos mais recentes da Tarja Editorial. Livro de Pedro Vieira @ nerdquest.

O carioca que cursa letras na UERJ nos brinda com uma obra que eu rotularia como algo próximo a uma Rapsódia-Thriller-Comédia -Relato-Desmorta-Fantástica continuação do Clássico Machadiano Memórias Póstumas de Brás Cubas!

Bem, sem mais palavras. Só digo uma coisa mais: Pobre de quem ainda não leu Memórias Desmortas de Brás Cubas! (Resenhas Memórias Desmortas de Brás Cubas, 2010).

O leitor, logo de início, utiliza o termo rapsódia para elencar como palavra-chave da resenha e, em seguida, o utiliza novamente no corpo do texto. A palavra faz alusão a uma composição, realizada de forma "livre", que possui características textuais de ordem clássica, elencada, geralmente, por justaposição. No contexto mais difundido, se tratava de um trecho de um poema épico a ser recitado.

De forma análoga, o leitor faz menção do termo por, certamente, vislumbrar uma conexão entre essa forma de composição e a obra contemporânea em destaque, assim como o faz com o que considera próximo de um thriller (expressão vinculada a produções de terror/horror), comédia (pelo sarcasmo/sátira empregados), relato/desmorta/fantástica (condizentes com o enredo e como ele é desenvolvido, em partes, sob forma de relato, conforme o clássico). Essa tentativa de enquadramento da obra, juntamente com o fato de mencionar a vida do autor, em tom de congratulações, denota uma relação de proximidade ou admiração para com Pedro Vieira.

A forma com que se expressa, remetendo ao enredo como avassalador/devorador ao consumar a leitura, lhe causando surpresa, só 
reforçam a ideia de que "[...] as formas do escrito ou as competências culturais dos leitores estreitam os limites da compreensão. Mas [...] a apropriação é criadora, produção de uma diferença [...]" (CHARTIER, 2010, p. 25).

Diante do entusiasmo empregado e utilizando de termos como de que o autor "nos brinda" com a obra e, ainda, "pobre" daquele que, porventura, não tiver conhecimento ou não tiver realizado a leitura dessa produção, vislumbra-se "[...] o fato de a literatura não poder ser, de fato, definida 'objetivamente'. A definição de literatura fica dependendo da maneira pela qual alguém resolve ler, e não da natureza daquilo que é lido" (EAGLETON, 2003, p. 11).

A última resenha em análise pertence ao usuário "JotaFF", o qual atribuiu quatro estrelas ao mash up:

Podemos dizer que tudo começou com o filme de George A. Romero de 1968 Night of the Living Dead, (A noite dos mortos vivos), onde os Zumbis levantam de seus túmulos e espalham o terror e a carnificina por onde passam. De lá para cá foram jogos, quadrinhos, mais filmes, livros, passeatas e convenções invadidas pelos devoradores de cérebro. Recentemente foi lançado no Brasil, o livro Orgulho e Preconceito e Zumbis, um mashup literário onde o autor, alterando mais ou menos uns $20 \%$ da obra original, encaixou os terríveis Zumbis na trama.

Pedro Vieira oferece outra alternativa em Memórias Desmortas de Brás Cubas. Diferente do que fizeram com o clássico de Jane Austen, o que temos aqui é uma continuação da obra de Machado de Assis.

Partindo da premissa clássica de um morto voltando a vida, temos um Brás Cubas saindo de seu caixão com força sobre humana, graças a sua zumbificação, com o conhecido apetite por Miolos, quando Prudêncio profana seu túmulo atrás do emplastro contra hipocondria. Esse é apenas o pontapé para uma madrugada de carnificina e zumbis.
0 autor se apropria de outros personagens das obras machadianas, que acabam se tornando vítimas nas mãos, ou dentadas, de zumbis famintos por miolos. Com linguagem renovada, e várias citações do mundo pop, ele emula a fórmula narrativa do Memórias Póstumas, com muito humor e ironia contra os estudos acadêmicos sobre literatura.

O propósito da obra é alcançar aqueles que se afastaram da literatura graças as aulas enfadonhas do colegial, quando éramos obrigados a ler e a responder questões de interpretação de texto de caráter duvidoso. $\mathrm{Na}$ medida do possível, também tenta deixar a obra atraente para aqueles que já gostavam da obra clássica. 0 humor ácido é dado na medida certa, mas as vezes exagera na quantidade de referências. Quem não for iniciado no mundo nerd e de tecnologia, pode não gostar. A não há pretensões de se aprofundar na trama, e isso funciona para nos deixar envolver pelo narrador [...] (Resenhas - Memórias Desmortas de Brás Cubas, 2010).

O leitor realiza um apanhado histórico-literário ao mencionar, em sua resenha, ao elencar, comparativamente, o enredo da obra a outras produções com temáticas similares, como o apocalipse zumbi. Isso mostra que o usuário tem um conhecimento considerável acerca de filmes e demais produções que desenvolvem essa temática, abrangendo, também, a ficção científica. Em outra passagem, deixa explícito que a obra encontra seu público, e esse é o público considerado nerd, os quais, comumente, acumulam um maior repertório de conhecimentos sobre os mais variados assuntos, e, provavelmente, seria capaz de identificar a maioria ou todas as referências elencadas no livro.

Contudo, em certa medida, apesar de elencar, ao longo do texto, referências de produções cujas temáticas são similares à obra Memórias Desmortas de Brás Cubas, o leitor pesa a crítica ao argumentar que o 
escritor traz muitas referências, tendendo ao exagero e, possivelmente, fragmentando a compreensão e a conexão do enredo para quem não estiver envolvido no mundo nerd. Esse argumento faz com que, de certa forma, ao contrário do que defende o senso comum e a crítica literária, obras apropriativas podem possuir prestígio diretamente ligado ao seu teor intelectual, embora concretizado à base de empréstimos de outras obras, o que não é ilegítimo, como colocado por Richard Shusterman (1998, p. 106): “[...] no domínio cultural, não há nada de intrinsecamente errado em emprestar conteúdo. Na esfera artística da cultura superior, o conteúdo sempre foi emprestado, e muitas vezes de fontes populares".

\section{Considerações finais}

Na contemporaneidade, os leitores, respaldados por uma era de convergência, comungam da condição de exporem, com mais segurança, suas percepções e conhecimentos acerca de noções literárias que carregam como verdades. Os espaços digitais, talvez por assegurarem uma identidade, muitas vezes difusa, de quem profere seus pareceres e as mais diversas opiniões, impulsionam a fluidez ou o inflamar de opiniões acerca das mais diversas produções literárias, tornando possíveis reflexões sobre como produções apropriativas estão tendo alcance, sendo consumidas e "julgadas" por seus leitores.

Assim como a temática de Memórias Desmortas de Brás Cubas, de Pedro Vieira, desenvolve a trajetória daquele que retornou dos mortos (a personagem Brás Cubas), a técnica do mash up literário, a releitura ou a paródia podem possibilitar o "reviver" de Machado de Assis e seu estilo de escrita perante os leitores (da plataforma). Dessa forma, também, é possível visualizar como as releituras dos clássicos podem contribuir, a nível de relevância, para deflagrar uma nova visão acerca do processo criativo de produções de autores na contemporaneidade e, possivelmente, uma ressignificação da relação entre autor canônico, soberania e originalidade.

Os leitores da plataforma Skoob, responsáveis por elaborar as resenhas em estudo, possuem opiniões muito diversas acerca, não somente, da nova produção, como também em relação ao que está se modificando no contexto criativo em nível literário. De forma geral, através do pronunciamento do dito "público não especializado", é visível que, guardadas as devidas proporções, reafirmam resistência sobre a apropriação textual - o nome do autor canônico ainda se sobrepõe à surpresa e à abertura a algo novo que, provavelmente, irá impactar na forma como sempre se enxergou Machado de Assis e suas obras - irretocáveis. Essa análise, portanto, pode colaborar para que sejam reavaliadas as noções arraigadas sobre a autoria e a originalidade no seio literário, alimentadas por tanto tempo pela crítica e por leitores que, bebendo da fonte de teóricos catedráticos que separam o cânone (no geral, homens brancos, ou assim representados) das demais obras, insistem em se apegar a uma hierarquia valorativa, hoje propícia a ser questionada.

Essas noções abalaram e ainda podem vir a afetar, durante algum tempo, algumas obras, sobretudo as contemporâneas, que perpassem por técnicas de apropriação mescladas a elementos "incomuns" com enredos outrora canônicos. Porém, tendo uma visão otimista, afirma Pedro Vieira (2010, p. 48), em sua obra: "Veja como a literatura [...] se torna tão agradável e excitante, bastando o acréscimo de uma pitada de carnificina sanguinolenta". 


\section{Referências}

ALMEIDA, A.N.S. 0 clássico resiste: releitura zumbi de Jane Austen e o incentivo à leitura. Revista Communitas, v.1, n. 2, jul./dez. 2017. Disponível em http://revistas.ufac.br/revista/ index.php/COMMUNITAS/article/view/1239/ pdf. Acesso em 28/05/2018.

BARTHES, Roland. A morte do autor. In: 0 rumor da língua. São Paulo: Martins Fontes, 2004. Disponível em http://www.artesplasticas.art. $\mathrm{br} /$ guignard/disciplinas/critica.../A_morte_do_ autor_barthes.pdf. Acesso em 30/04/2018.

BENJAMIN, Walter. A obra de arte na era da reprodutibilidade técnica. In: Magia e técnica, arte e política: ensaios sobre literatura e história da cultura. São Paulo: Brasiliense, 1968, p. 165-170.

BOURRIAUD, Nicolas. Pós-produção: como a arte reprograma o mundo contemporâneo. Tradução de Denise Bottmann. São Paulo: Martins Fontes, 2009.

BURLAMAQUE, Fabiane Verardi; BARTH, Pedro Afonso. Redes sociais e o ensino: o Skoob como ferramenta para o letramento digital e literário. Nuances: estudos sobre Educação, Presidente Prudente - SP, v. 26, n. 3, p. 53-73, set./dez. 2015. Disponível em <http:// dx.doi. org/10.14572/nuances.v26i3.3838>. Acesso em $11 / 2019$.

BUZATO, Marcelo El Khouri. Et. al. Remix, mashup, paródia e companhia: por uma taxonomia multidimensional da transtextualidade na cultura digital. Revista Brasileira de Linguística Aplicada, Belo Horizonte, vol.13, n.4, Oct/Dec, 2013. Disponível em: http://dx. doi.org/10.1590/S1984-63982013000400011 . Acesso em 12/05/2018.

CASTRO, Fernanda Meneses de Miranda; SPINOLA, Carolina de Andrade. Metodologia de pesquisas na internet: breves considerações sobre uma pesquisa qualitativa em turismo nas redes sociais. Revista Iberoamericana de Turismo - RITUR, Penedo, vol. 5, n. 1, p. 170-188, 2015. Disponível em <http:// www.seer.ufal.br / index.php/ritur>. Acesso em 10/2019.

CEIA, Carlos. E-Dicionário de termos literários. Disponível em http://www.aedi.ufpa.br/ parfor/letras/images/pdf/at_distancia/bra- ganca_1.2013/capanema_2010/1.2013\%20 capanema\%202010\%20literatura\%20portuguesa $\% 20$ contempornea-verbetes $\% 20$ pastiche $\% 20$ parodia-profa. $\% 20$ alessandra $\% 20$ conde.pdf. Acesso em 21/01/2020.

CHARTIER, Roger. Escutar os mortos com os olhos. In: Estudos Avançados; Revista do Instituto de Estudos Avançados da Universidade de São Paulo. Trad. Jean Briant, São Paulo, 2010, v. 24, n. 69. pp. 7-30. Disponível em http://www.revistas.usp.br/eav/article/ view/10510/12252. Acesso em 25/01/2020.

EAGLETON, Terry. 0 que é literatura? In: Teoria da literatura: uma introdução. Tradução: Waltensir Dutra. Martins Fontes, São Paulo, 2003.

JESUS, I.S.S. de; PEREIRA, V.C. Instância autoral morta-viva em Orgulho e Preconceito e Zumbis. Revista do Programa de Pós-Graduação em Letras da Universidade de Passo Fundo. v. 11-n.1-p. 155-169-jan./jun. 2015. Disponível em http://seer.upf.br/index.php/rd/article/ view/5035. Acesso em 27/05/2018.

KRAUSE, James Remington. Three contemporary brazilian parody mashup novels. In: Scripta Uniandrade, v. 15, n. 1, 2017, Disponível em https://uniandrade.br/revistauniandrade/index.php/ScriptaUniandrade/article/ view/720. Acesso em 25/01/2020.

LIMA, Luiz Costa. A literatura e o leitor: textos de estética da recepção. Rio de Janeiro: Paz e Terra, 1979.

Livraria da Folha. Dom Casmurro e os discos voadores recria clássico sob perspectiva da ficção científica. Texto de Paula Dume, 2010. Disponível em http://www1.folha.uol.com.br/ folha/livrariadafolha/808436-dom-casmurro-e -os-discos-voadores-recria-classico-sob-perspectiva-da-ficcao-cientifica.shtml. Acesso em 01/06/2018.

MELLO, Marisa Schincariol de. Práticas de leitura na contemporaneidade: experiências em bibliotecas na cidade do Rio de Janeiro. In: Pragmatizes: Revista latinoamericana de estudos em cultura, ano 7, número 12, 2017.

OLIVEIRA, Sayonara Amaral de. Aos cuidados de Paulo Coelho.com: um estudo de recepção nos blogs do escritor. Salvador: EDUFBA, 2015.

REIS, Roberto. Cânon. In: Palavras da crí- 
tica. Rio de Janeiro: Imago, 1992. Disponível em https://social.stoa.usp.br/articles/0037/3007/C_NON_-_roberto_reis.pdf. Acesso em 01/05/2018.

Resenhas - Memórias Desmortas de Brás Cubas. Disponível em <https://www. skoob.com.br/livro/resenhas/123065/edicao:136581>. Acesso em 02/04/2020.

RODRIGUES, Sheila Darcy Antonio. Mash up brasileiro, a coleção Clássicos Fantásticos: a literatura como produto do mercado editorial. Universidade Presbiteriana Mackenzie: São Paulo, 2013. Disponível em http://tede. mackenzie.br/jspui/handle/tede/2181\#preview-link0. Acesso em 01/05/2018.

SHUSTERMAN, Richard. Forma e funk: o desafio estético da arte popular. In: Vivendo a arte: o pensamento pragmatista e a estética popular. Tradução Gisela Domschke. São Paulo: ed. 34, 1998.

Skoob. Disponível em <https://www.skoob. com.br/>.

Skoob - Memórias Desmortas de Brás Cubas - Pedro Vieira. Disponível em https://www. skoob.com.br/memorias-desmortas-de-brascubas-123065ed136581.html. Acesso em 09/11/2019.

STIERLE, Karlheinz. Que significa a recepção de textos ficcionais? In: LIMA, L.C. A literatura e o leitor: textos de estética da recepção. Rio de Janeiro: Paz e Terra, 1979.

VIEIRA, Pedro. Entrevista concedida pela plataforma Gmail, setembro de 2019.

VIEIRA, Pedro. Memórias Desmortas de Brás Cubas. São Paulo: Tarja Editorial, 2010.

VILLA-FORTE, Leonardo. Escrever sem escrever: literatura e apropriação no século XXI. Rio de Janeiro: Ed. PUC-RIO; Belo Horizonte, MG: Relicário, 2019.

ZAPPONE, Mirian Hisae Yaegashi. Estética da recepção. In: Thomas Bonnici; Lucia Osana Zolin. (Org.). Teoria Literária: abordagens históricas e tendências contemporâneas. 3ed. Maringá: EDUEM, 2009, v. 1, p. 189-200. Disponível em http://paginapessoal.utfpr.edu.br/cantarin/ fundamentos-e-critica-da-literatura/seminarios-i/Estetica\%20da\%20Recepcao.pdf/at_download/file. Acesso em 26/07/2019.

ZILBERMAN, Regina. Recepção e leitura no horizonte da literatura. In: Alea: Estudos neolatinos, vol. 10. Rio de Janeiro, 2008. Disponível em http://www.scielo.br/scielo.php?script=sci_arttext\&pid=S1517-106X2008000100006. Acesso em 25/01/2020.
Recebido em: $19 / 05 / 2020$

Aprovado em: 15/07/2020 